\title{
Isolation and characterization of antioxidant constituents of the fruit of Telfairia occidentalis Hook F (Cucurbitaceae)
}

\author{
Olorunfemi A Eseyin ${ }^{1 *}$, Uduak Benedict ${ }^{2}$, Paul S Thomas ${ }^{2}$, Iweh Etim¹, \\ Emmanuel Essien ${ }^{3}$, Ekarika Johnson ${ }^{1}$, Aniekan Ebong ${ }^{1}$, Zubaid Munavvar ${ }^{4}$, \\ Ashfaq Ahmad ${ }^{5}$, Afzal Sheryar ${ }^{4}$, Ukeme Akpan ${ }^{6}$ \\ ${ }^{1}$ Department of Pharmaceutical and Medicinal Chemistry, Faculty of Pharmacy, University of Uyo, Uyo, Nigeria, ${ }^{2}$ Department of \\ Pharmacognosy and Natural Medicine, Faculty of Pharmacy, ${ }^{3}$ Department of Chemistry, Faculty of Science, University of Uyo, \\ Uyo, Nigeria, ${ }^{4}$ Faculty of Pharmacy, Mahsa University, Kuala Langat, Selangor, Malaysia, ${ }^{5}$ Department of Pharmacology, \\ Virginia Commonwealth University, Richmond, USA, ${ }^{6}$ Department of Inspection and Enforcement, National Environmental \\ Standards and Regulations Enforcement Agency, Abuja, Nigeria
}

*For correspondence: Email: olorunfemieseyin.pharm.lect@uniuyo.edu.ng; Tel: +234-8065161478

Sent for review: 19 April 2018

Revised accepted: 9 September 2018

\begin{abstract}
Purpose: To evaluate the antioxidant property of the fruit of Telfairia occidentalis and isolate the components responsible for the antioxidant activity.

Methods: The fruit pericarp was macerated with methanol and the extract obtained successively partitioned with $n$-hexane, dichloromethane and ethyl acetate. The in vitro antioxidant activity of the extract and fractions was evaluated using 2,2-diphenyl-1-picryl hydrazyl (DPPH) radical scavenging, reducing power, nitric oxide scavenging, total antioxidant and hydrogen peroxide scavenging assays. The $n$-hexane fraction, which had the highest DPPH scavenging and total antioxidant activities, was subjected to column and thin layer chromatography to isolate the components. The isolated compounds were identified by ultraviolet-visible (UV), nuclear magnetic resonance (NMR), Fourier transform infrared (FTIR) spectroscopy and mass spectrometry.

Results: Among the fractions tested, $n$-hexane had the best total antioxidant activity of $99.44 \%$ at 20 $\mathrm{mg} / \mathrm{ml}(\mathrm{p}<0.05)$ compared to ascorbic acid at $99.71 \%$ of $20 \mathrm{mg} / \mathrm{ml}$. This fraction also had the highest $D P P H$ radical scavenging activity of all the fractions $(p<0.05)$ at all test concentrations. For nitric oxide scavenging activity, the whole extract, and the chloroform and aqueous fractions exhibited activity ranging from 92.29 to $97.66 \%$ compared to $98.93 \%$ for ascorbic acid. The hydrogen peroxide scavenging activity of the extract and fractions ranged from 92.60 to $96.23 \%$ compared with of the standard, ascorbic acid (101.68\%). The major components of the $n$-hexane fractions were $\alpha$ - amyrin and $\beta$-amyrin.

Conclusion: The fruit pericarp of Telfairia occidentalis possesses good DPPH radical scavenging activity. This is the first time the antioxidant activity of the fruit (pericarp) and the presence of $\alpha$ - and $\beta$ amyrins in Telfairia occidentalis have been reported.
\end{abstract}

Keywords: Telfairia occidentalis, Fluted pumpkin, Amyrin, Antioxidants

\begin{abstract}
This is an Open Access article that uses a funding model which does not charge readers or their institutions for access and distributed under the terms of the Creative Commons Attribution License (http://creativecommons.org/licenses/by/4.0) and the Budapest Open Access Initiative (http://www.budapestopenaccessinitiative.org/read), which permit unrestricted use, distribution, and reproduction in any medium, provided the original work is properly credited.
\end{abstract}

Tropical Journal of Pharmaceutical Research is indexed by Science Citation Index (SciSearch), Scopus, International Pharmaceutical Abstract, Chemical Abstracts, Embase, Index Copernicus, EBSCO, African Index Medicus, JournalSeek, Journal Citation Reports/Science Edition, Directory of Open Access Journals (DOAJ), African Journal Online, Bioline International, Open-J-Gate and Pharmacy Abstracts 


\section{INTRODUCTION}

Telfairia occidentalis is popularly known mainly because of its nutritionally valuable leaves [1]. The leaves have high nutritive value compared with other vegitables grown in the tropics. The seed is also edible. Telfairia occidentalis is popular among herbal practitioners. A review of the medicinal properties of the plant was written by Eseyin et al [2]. Telfairia occidentalis possesses antioxidant property [3].

Not much work has been done on the fruit pericarp of the plant which is usually discarded as it is often considered not useful. There is therefore no available report on the antioxidant activity or isolated component of the fruit pericarp of Telfairia occidentalis. Since the leaf and seed of Telfairia occidentalis have been found to possess significant antioxidant properties, the authors decided to screen the fruit pericarp for antioxidant property and isolate the antioxidant components of the pericarp.

\section{EXPERIMENTAL}

\section{Plant collection and identification}

The fruit of Telfairia occidentalis (Fluted pumpkin) was obtained from the medicinal plant farm of the Faculty of Pharmacy, University of Uyo, Akwa Ibom State, Nigeria in June 2015. The fruits were identified by Professor Margaret Bassey in the Department of Botany and Ecological Studies University of Uyo, Akwa Ibom State, Nigeria and it was assigned voucher number UUPH28 (d). A voucher specimen was kept in the faculty of Pharmacy, University of Uyo, herbarium.

\section{Preparation and extraction of plant material}

The freshly collected and identified fruits of Telfairia occidentalis were sliced opened and the pulp and the seed removed. The pericarp was chopped into small bits and air dried. Methanol (95\%, 5 litres) was poured into a container containing $500 \mathrm{~g}$ of the dried fruit material and macerated for $72 \mathrm{~h}$ at ambient temperature with intermittent shaking. The liquid extract was filtered and concentrated in vacuo. The extract was further dried in a desiccator containing selfindicating silica gel orange (Sigma-Aldrich, Germany).

\section{Partitioning of the extract}

The dried methanol extract $(85 \mathrm{~g})$ was dissolved in $500 \mathrm{~mL}$ of distilled water and partitioned successively with n-hexane, dichloromethane and ethyl acetate to obtain their respective fractions. Each of the fractions was concentrated in a rotary evaporator to dryness.

\section{Evaluation of antioxidant properties}

The DPPH antioxidant capacity of the extracts, vitamin $C$ and $E$ were evaluated by the method of Enujiugha [4]. A dose of $0.2 \mathrm{~mL}$ of the extracts was added to $3.8 \mathrm{~mL}$ ethanol solution of DPPH radical until a final concentration of $0.1 \mathrm{mM}$ was obtained. The mixture was agitated vigorously for $1 \mathrm{~min}$ and left to stand at room temperature for $30 \mathrm{~min}$. The absorbance of each sample (As) was measured on a UV spectrophotometer at $517 \mathrm{~nm}$ against ethanol blank. Negative control (A) was taken after adding DPPH solution to 0.2 $\mathrm{mL}$ of the extracts. DPPH scavenging activity (D) of the sample was calculated as in Eq 1.

$D(\%)=\{(\mathrm{Ac}-\mathrm{As}) / \mathrm{Ac}\}$

where Ac and As are the absorbance of control and test compound, respectively.

The reducing power assay was estimated by the method of Athukorala et al [5]. $1.0 \mathrm{~mL}$ extract was mixed with $2.5 \mathrm{~mL}$ of phosphate buffer (20 $\mathrm{mM}, \mathrm{pH}$ 6.6) and $2.5 \mathrm{~mL}$ of potassium ferricyanide $(30 \mathrm{mM})$ and incubated at $50{ }^{\circ} \mathrm{C}$ for 20 minutes. Thereafter, $2.5 \mathrm{~mL}$ of trichloroacetic acid $(600 \mathrm{mM})$ was added to the reaction mixture, centrifuged for 10 minutes at $3000 \mathrm{rpm}$. The upper layer of the solution $(2.5 \mathrm{~mL})$ was mixed with $2.5 \mathrm{~mL}$ of distilled water and $0.5 \mathrm{~mL}$ of $\mathrm{FeCl}_{3}(6 \mathrm{mM})$ and absorbance was measured at $700 \mathrm{~nm}$. Nitric oxide (NO) scavenging activity was estimated by the method of Green et al [6]. Sodium nitroprusside (10 $\mathrm{mM}, 3 \mathrm{~mL})$ in phosphate buffer was added to $2.0 \mathrm{~mL}$ of extract and reference compound in different concentrations (20 - $100 \mathrm{~g} / \mathrm{ml})$.

The resulting solutions were then incubated at 25 ${ }^{\circ} \mathrm{C}$ for 60 minutes. A similar procedure was repeated with methanol as blank, which served as control. To $2.0 \mathrm{~mL}$ of the incubated sample, $5.0 \mathrm{~mL}$ of Griess reagent $(1 \%$ sulphanilamide, $0.1 \%$ naphthyethylene diamine dihydrochloride in $2 \% \mathrm{H}_{3} \mathrm{PO}_{3}$ ) was added and absorbance of the chromophore formed was measured at $540 \mathrm{~nm}$. The total antioxidant activity was evaluated using the method of Lingnert [7]. Each extract (0.1-20 $\mathrm{mg} / \mathrm{ml})$ in water or ethanol $(100 \mu \mathrm{l})$ was mixed with $2.0 \mathrm{~mL}$ of $10 \mathrm{mM}$ linoleic acid emulsion in $0.2 \mathrm{M}$ sodium phosphate buffer $(\mathrm{pH} 6.6)$ in a test tube and kept in the dark at $37{ }^{\circ} \mathrm{C}$ to accelerate oxidation. After incubation for $15 \mathrm{~h}, 0.1 \mathrm{~mL}$ from each tube was mixed with $7.0 \mathrm{~mL}$ of $80 \%$ methanol in deionized water and the absorbance 
of the mixture was measured at $234 \mathrm{~nm}$ against a blank in a spectrophotometer. Antioxidant activity (D) was calculated as as in Eq 2.

$D(\%)=\{(A c-A s) / A c\}$

where Ac and As are the absorbance of control and test compound, respectively.

Hydrogen peroxide scavenging activity was evaluated according to the method of Ruch et al [8]. A solution of hydrogen peroxide $(40 \mathrm{mM})$ was prepared in phosphate buffer $(50 \mathrm{mM}, \mathrm{pH}$ 7.4). The concentration of hydrogen peroxide was determined by absorption at $230 \mathrm{~nm}$ using a spectrophotometer. Extract (20 - 60 g/mL) dissolved in distilled water was added to hydrogen peroxide and absorbance at $230 \mathrm{~nm}$ was determined after $10 \mathrm{~min}$ against a blank without hydrogen peroxide. Hydrogen peroxide scavenging $\mathrm{H}(\%)$ was calculated as in Eq 3.

$H(\%)=\{(A c-A s) / A c\}$

where Ac and As are the absorbance of control and test compound, respectively.

Isolation and purification of compounds in $\mathbf{n}$ hexane fraction

The dried n-hexane fraction $(9.13 \mathrm{~g})$ which had the highest DPPH and total antioxidant activities was subjected to open column chromatography (Rotaflo glass column (Quick-fit, England) measuring 3 x $80 \mathrm{~cm}$; silica gel-G mesh 60 - 120 (Burgoyne, India). The flow rate of the eluent was kept constant at about $1 \mathrm{~mL} / \mathrm{min}$ and the fractions were collected in $20 \mathrm{~mL}$ test tube. The sample was eluted using solvent systems that consisted of varying percent of two of the following solvents at a time in the specified order Pentane, $\mathrm{n}$ - hexane, $\mathrm{CHCl}_{3}$, EtOAC and, $\mathrm{MeOH}$ to obtain 291 eluates. The eluates were monitored by TLC (silica gel; solvent system: pentane 10: $n$ - hexane 9: ethyl acetate 1) and visualized using Ultraviolet lamp (366 nm) (Allen, London) and appropriate detecting reagents such as $1 \%$ anisaldehyde in $10 \% \mathrm{H}_{2} \mathrm{SO}_{4}, 5 \% \mathrm{FeCl}_{3}$ and conc. $\mathrm{H}_{2} \mathrm{SO}_{4}$.

Eluates with same $R_{f}$ values were pooled together to obtain fractions $A, B, C, D, E, F$ and G. Fraction D (3500 mg) was further purified using open column chromatography (silica gel-G; 60 - 120 mesh). The fraction was separated using n-hexane and $\mathrm{CHCl}_{3}$ (starting with $100 \%$ n-hexane, varying ratio of the two solvents and $100 \% \mathrm{CHCl}_{3}$ ) to obtain 40 eluates which were pooled together based on similarity in $\mathrm{Rf}$ values to obtain different fractions. Fraction D2 (eluate
12 - 36; $3300 \mathrm{mg}$ ) gave a spot tailing on TLC (silica gel; solvent system: pentane 10: $\mathrm{n}$ hexane 5: ethyl acetate 1) under UV: $366 \mathrm{~nm}$. Fraction D2 was purified further using Sephadex LH-20 (Pharmacia Fine Chemicals, Sweden) as the stationary phase while ethanol (100\%) was used to elute the fraction to obtain BEN- 4 (pure white compound, $1951 \mathrm{mg}$ ) which gave a single spot on TLC.

Fraction E (2570 mg) was also subjected to further purification using column chromatography with silica gel-G (60 - 120 mesh) using $n$ hexane $(100 \%)$, mixtures of $n$-hexane and $\mathrm{CHCl}_{3}$ (varying ratios), $\mathrm{CHCl}_{3}(100 \%)$, different ratios of $\mathrm{CHCl}_{3}$ and EtOAC, and EtOAC (100\%). The fraction was separated using appropriate solvent systems to obtain four fractions. Eluate 1-48 gave Fraction E1 (one spot tailing, white amorphous, $1730 \mathrm{mg}$ ) which was subjected to further purification with column chromatography (Sephadex LH-20, solvent system: starting with $100 \% \mathrm{n}$ - hexane, varying ratio of the two solvents and $100 \% \mathrm{CHCl}_{3}$ ) to obtain BEN-7 (1343 mg) which was a pure compound with $R_{f}$ values of 0.38 (silica gel; solvent system: $n-$ hexane 10: ethyl acetate 2), 0.74 (silica gel; solvent system: n-hexane 10: ethyl acetate 4), 0.40 (silica gel; solvent system: n-hexane 4: chloroform 8) and 0.54 (silica gel; solvent system: n-hexane 4: chloroform 10).

\section{Spectroscopic analyses}

\section{Ultraviolet spectroscopy}

The UV spectra of isolated compounds were obtained using a UV spectrophotometer (Unico UV-2100 Spectrophotometer, Shanghai Instruments Co, Ltd., China).

\section{Nuclear magnetic resonance}

The isolates where weighed $(10 \mathrm{mg})$ and dissolved in deuterioted chloroform $\left(\mathrm{CDCl}_{3}\right)$. The solution was introduced into sample tubes, and was inserted into the NMR spectrometer (Bruker Avance AV 400, 400.033 MHz) equipped with a $5 \mathrm{~mm}$ DUL 13C-1 z-gradient probe head. The machine was operated by means of a computer to obtain the different NMR spectra. The proton and Carbon NMR (including 2-dimensional Carbon NMR: COSY and NOESY) spectra were acquired.

\section{Fourier transform infra-red spectroscopy (FTIR)}

The isolates where weighed (10 mg) and dissolved in dichloromethane. The solution was 
introduced into sample tubes, and was inserted into the infra-red spectrometer (JASCO 302-A) to obtain the IR spectra.

\section{Mass spectrometry (MS)}

The isolates were weighed $(10 \mathrm{mg})$ and dissolved in dichloromethane. The solution was introduced into sample tubes, and was inserted into the mass spectrometer (ionization voltage 70 eV; JEOL JMS-600H). The machine was operated by means of a computer to obtain the MS spectra.

\section{Statistical analysis}

The data obtained are expressed as mean \pm SEM and were subjected to one-way analysis of variance (ANOVA) using GraphPad Prism 5.01 (USA). Values of $p<0.05$ were considered significant.

\section{RESULTS}

The yield of methanol extract, $\mathrm{n}$ - hexane, chloroform, ethyl acetate and aqueous fractions are $15.7,11.87,5.49,26.60$ and $51.63 \%$, respectively. There were significant variations in the antioxidant activity of the different fractions based on the method used. Some fractions showed very high antioxidant activity in one or more methods but less in other models. Table 1 shows the results for DPPH scavenging property of extract and fractions of the pericarp of Telfairia occidentalis. Table 2 and Table 3 show the results for reducing power and nitric oxide scavenging activities for extract and fractions, respectively, while those for hydrogen peroxide scavenging and total antioxidant activities of extract and fractions are depicted in Table 4 and Table 5, respectively. Table 6 displays the results for antioxidant activity of the isolated compounds based on DPPH-radical scavenging.

The $\mathrm{n}$ - hexane fraction which had the highest total antioxidant and DPPH-radical scavenging activities was purified further on column chromatography to obtain two compounds coded BEN-4 and BEN-7. From the proton NMR spectra, COSY, NOESY, MS and IR spectra, BEN-4 was identified as alpha-amyrin (1) and BEN-7 as beta-amyrin (2).

Table 1: DPPH-radical scavenging activity of extract and fractions of the fruit of $T$. occidentalis

\begin{tabular}{lccccc}
\hline Antioxidant & \multicolumn{5}{c}{ Antioxidant concentration (g/mL) } \\
\cline { 2 - 6 } & $\mathbf{2 0}$ & $\mathbf{4 0}$ & $\mathbf{6 0}$ & $\mathbf{8 0}$ & $\mathbf{1 0 0}$ \\
\cline { 2 - 6 } Vitamin C & $1.194 \pm 0.689$ & $1.222 \pm 0.706$ & $1.232 \pm 0.711$ & $1.239 \pm 0.715$ & $1.244 \pm 0.718$ \\
& $(74.65 \%)$ & $(78.26 \%)$ & $(79.52 \%)$ & $(80.41 \%)$ & $(81.01 \%)$ \\
Extract & $0.640 \pm 0.370^{*}$ & $0.681 \pm 0.393^{*}$ & $0.683 \pm 0.394^{*}$ & $0.758 \pm 0.438^{*}$ & $0.794 \pm 0.458^{*}$ \\
& $(68.34 \%)$ & $(70.75 \%)$ & $(70.84 \%)$ & $(75.67 \%)$ & $(78.18 \%)$ \\
N-hexane & $0.782 \pm 0.451$ & $0.822 \pm 0.475$ & $0.898 \pm 0.518^{*}$ & $0.902 \pm 0.521^{*}$ & $0.913 \pm 0.527$ \\
& $(77.37 \%)$ & $(80.23 \%)$ & $(86.05 \%)$ & $(86.40 \%)$ & $(82.30 \%)$ \\
Ethyl acetate & $0.374 \pm 0.216^{*}$ & $0.390 \pm 0.225^{*}$ & $0.514 \pm 0.297^{*}$ & $0.628 \pm 0.363^{*}$ & $0.645 \pm 0.373^{*}$ \\
& $(52.26 \%)$ & $(56.80 \%)$ & $(61.72 \%)$ & $(67.62 \%)$ & $(68.60 \%)$ \\
Chloroform & $0.535 \pm 0.309^{*}$ & $0.510 \pm 0.294^{*}$ & $0.326 \pm 0.188^{*}$ & $0.307 \pm 0.177$ & $0.283 \pm 0.163^{*}$ \\
& $(53.58 \%)$ & $(45.62 \%)$ & $(45.26 \%)$ & $(38.37 \%)$ & $(37.21 \%)$ \\
Aqueous & $0.634 \pm 0.366^{*}$ & $0.553 \pm 0.319^{*}$ & $0.457 \pm 0.264^{*}$ & $0.089 \pm 0.051$ & $0.647 \pm 0.374^{*}$ \\
& $(67.98 \%)$ & $(63.69 \%)$ & $(55.01 \%)$ & $(49.64 \%)$ & $(31.31 \%)$ \\
\hline
\end{tabular}

Absorbance values are expressed as mean \pm standard deviation; \% scavenging activity is expressed in bracket.

*Significant difference compared to ascorbic acid $(p<0.05)$

Table 2: Reducing power activity of extract and fractions of the fruit of $T$. occidentalis

\begin{tabular}{lccc}
\hline \multirow{3}{*}{} & \multicolumn{3}{c}{ Antioxidant concentration $(\mathbf{g} / \mathrm{mL})$} \\
\cline { 2 - 4 } & $\mathbf{1 0}$ & $\mathbf{2 0}$ & $\mathbf{3 0}$ \\
\cline { 2 - 4 } Antioxidant & \multicolumn{3}{c}{ Absorbance } \\
\hline Vitamin C & $0.553 \pm 0.319$ & $1.866 \pm 1.077$ & $1.867 \pm 1.078$ \\
Extract & $0.500 \pm 0.287^{*}$ & $0.583 \pm 0.337^{*}$ & $0.587 \pm 0.339^{*}$ \\
N-hexane & $0.540 \pm 0.312$ & $0.598 \pm 0.345^{*}$ & $0.603 \pm 0.348^{*}$ \\
Ethyl acetate & $0.520 \pm 0.300$ & $0.588 \pm 0.339^{*}$ & $0.640 \pm 0.370^{*}$ \\
Chloroform & $0.613 \pm 0.354$ & $0.607 \pm 0.350^{*}$ & $0.567 \pm 0.327^{*}$ \\
Aqueous & $0.580 \pm 0.335$ & $0.531 \pm 0.307^{*}$ & $0.520 \pm 0.300^{*}$ \\
\hline
\end{tabular}

Absorbance values are expressed as mean \pm standard deviation. *Significant difference compared to ascorbic acid $(p<0.05)$ 
Table 3: Nitric oxide scavenging assay of extract and fractions of the fruit of $T$. occidentalis

\begin{tabular}{llll}
\hline & \multicolumn{3}{c}{ Antioxidant concentration (g/mL) } \\
\cline { 2 - 4 } Antioxidant & \multicolumn{1}{c}{$\mathbf{2 0}$} & \multicolumn{1}{c}{$\mathbf{4 0}$} & \multicolumn{1}{c}{$\mathbf{6 0}$} \\
\cline { 2 - 4 } Vitamin C & $1.671 \pm 1.247$ & $1.694 \pm 0.978$ & $1.694 \pm 0.978$ \\
& $(98.93 \%)$ & $(95.49 \%)$ & $(95.19 \%)$ \\
Extract & $1.643 \pm 0.949$ & $1.642 \pm 0.948$ & $1.642 \pm 0.948$ \\
& $(95.15 \%)$ & $(95.08 \%)$ & $(95.08 \%)$ \\
N-hexane & $1.666 \pm 0.962$ & $1.664 \pm 0.961$ & $1.644 \pm 0.949$ \\
& $(96.39 \%)$ & $(96.29 \%)$ & $(95.22 \%)$ \\
Ethyl acetate & $1.675 \pm 0.967$ & $1.670 \pm 0.930$ & $1.667 \pm 0.962$ \\
& $(96.89 \%)$ & $(96.62 \%)$ & $(96.49 \%)$ \\
Chloroform & $1.682 \pm 0.971$ & $1.680 \pm 0.970$ & $1.675 \pm 0.967$ \\
& $(97.29 \%)$ & $(97.19 \%)$ & $(96.92 \%)$ \\
Aqueous & $1.688 \pm 0.975$ & $1.674 \pm 0.966$ & $1.670 \pm 0.964$ \\
& $(97.66 \%)$ & $(96.86 \%)$ & $(96.62 \%)$ \\
\hline
\end{tabular}

Absorbance values are expressed as mean \pm standard deviation; \% scavenging activity is expressed in bracket. *Significant difference compared to ascorbic acid $(p<0.05)$

Table 4: Hydrogen peroxide scavenging activity of the extract and fractions of the fruit of $T$. occidentalis

\begin{tabular}{lccc}
\hline & \multicolumn{3}{c}{ Antioxidant concentration (g/mL) } \\
\cline { 2 - 4 } Antioxidant & $\mathbf{2 0}$ & $\mathbf{4 0}$ \\
\cline { 2 - 4 } Vitamin C & $1.922 \pm 1.110$ & $1.897 \pm 1.095$ & $\mathbf{2 0}$ \\
\cline { 2 - 4 } Extract & $(101.68 \%)$ & $(99.09 \%)$ & $(98.38 \%)$ \\
& $1.817 \pm 1.049^{*}$ & $1.832 \pm 1.058^{*}$ & $1.840 \pm 1.062$ \\
N-hexane & $(95.46 \%)$ & $(96.17 \%)$ & $(96.59 \%)$ \\
& $1.674 \pm 0.966^{*}$ & $1.718 \pm 0.992^{*}$ & $1.763 \pm 1.018^{*}$ \\
Ethyl acetate & $(88.58 \%)$ & $(90.61 \%)$ & $(92.76 \%)$ \\
& $1.759 \pm 1.016^{*}$ & $1.797 \pm 1.037^{*}$ & $1.860 \pm 1.074$ \\
Chloroform & $(92.60 \%)$ & $(94.44 \%)$ & $(97.61 \%)$ \\
& $1.833 \pm 1.058^{*}$ & $1.843 \pm 1.064^{*}$ & $1.859 \pm 1.073$ \\
Aqueous & $(96.23 \%)$ & $(96.72 \%)$ & $(97.55 \%)$ \\
& $1.804 \pm 1.042^{*}$ & $1.826 \pm 1.054^{*}$ & $1.828 \pm 1.055$ \\
\hline
\end{tabular}

Absorbance values are expressed as mean \pm standard deviation; \% scavenging activity is expressed in bracket. *Significant difference compared to ascorbic acid $(p<0.05)$

Table 5: Total antioxidant assay of the extract and fractions of the fruit of $T$. occidentalis

\begin{tabular}{lccccc}
\hline & \multicolumn{5}{c}{ Antioxidant concentration (g/mL) } \\
\cline { 2 - 6 } Antioxidant & $\mathbf{2 0}$ & $\mathbf{4 0}$ & $\mathbf{6 0}$ & $\mathbf{8 0}$ & $\mathbf{1 0 0}$ \\
\cline { 2 - 6 } & & \multicolumn{5}{c}{ Absorbance } \\
\hline Vitamin C & $1.861 \pm 1.074$ & $1.857 \pm 1.072$ & $1.847 \pm 1.066$ & $1.837 \pm 1.061$ & $1.825 \pm 1.054$ \\
& $(99.71 \%)$ & $(99.31 \%)$ & $(98.27 \%)$ & $(97.15 \%)$ & $(95.88 \%)$ \\
Extract & $1.734 \pm 1.001^{*}$ & $1.727 \pm 0.997^{*}$ & $1.714 \pm 0.990^{*}$ & $1.699 \pm 0.981^{*}$ & $1.632 \pm 0.969^{*}$ \\
& $(93.29 \%)$ & $(92.92 \%)$ & $(92.28 \%)$ & $(91.59 \%)$ & $(90.56 \%)$ \\
N-hexane & $1.757 \pm 1.014^{*}$ & $1.739 \pm 1.004^{*}$ & $1.731 \pm 0.999^{*}$ & $1.708 \pm 0.986^{*}$ & $1.704 \pm 0.984^{*}$ \\
& $(94.44 \%)$ & $(93.52 \%)$ & $(93.15 \%)$ & $(92.00 \%)$ & $(91.79 \%)$ \\
Ethyl acetate & $1.692 \pm 0.977^{*}$ & $1.681 \pm 0.971^{*}$ & $1.663 \pm 0.962^{*}$ & $1.667 \pm 0.962^{*}$ & $1.633 \pm 0.943^{*}$ \\
& $(91.22 \%)$ & $(90.70 \%)$ & $(89.81 \%)$ & $(89.35 \%)$ & $(88.45 \%)$ \\
Chloroform & $1.683 \pm 0.972^{*}$ & $1.671 \pm 0.965^{*}$ & $1.671 \pm 0.965^{*}$ & $1.642 \pm 0.948^{*}$ & $1.637 \pm 0.945^{*}$ \\
& $(90.79 \%)$ & $(90.21 \%)$ & $(89.43 \%)$ & $(88.80 \%)$ & $(88.60 \%)$ \\
Aqueous & $1.700 \pm 0.981^{*}$ & $1.682 \pm 0.971^{*}$ & $1.672 \pm 0.965^{*}$ & $1.651 \pm 0.953^{*}$ & $1.632 \pm 0.942^{*}$ \\
& $(91.59 \%)$ & $((90.73 \%)$ & $(90.24 \%)$ & $(89.26 \%)$ & $(88.37 \%)$ \\
\hline \multicolumn{1}{c}{ Absorbance values are expressed as mean $\%$ standard deviation. \%cavenging activity is expressed in bracket. }
\end{tabular}

Absorbance values are expressed as mean \pm standard deviation. \% scavenging activity is expressed in bracket.

* Significant difference compared to ascorbic acid $(p<0.05)$ 
Table 6: DPPH-radical scavenging assay of the isolated compounds

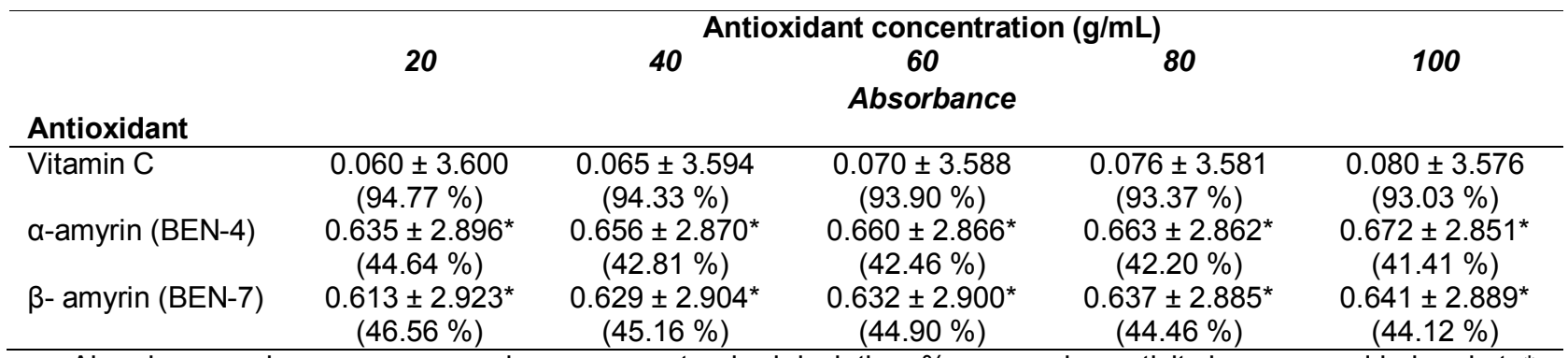

Absorbance values are expressed as mean \pm standard deviation. \% scavenging activity is expressed in bracket. * Significant difference compared to Ascorbic acid $(p<0.05)$

\section{Spectral data}

BEN - 4 was obtained as a white solid amorphous compound, melting point $180-186$ ${ }^{\circ} \mathrm{C}$; IR (Vmax, cm-1) 3342 (OH stretch), 2947 $\left(\mathrm{CH}_{3}, \quad \mathrm{CH}_{2} ;\right.$ asymmetric stretch) $1639(\mathrm{C}=\mathrm{C}$ stretch) $1379\left(\mathrm{CH}_{3}, \mathrm{CH}_{2}\right.$; symmetric bending), $1460\left(\mathrm{CH}_{3}, \mathrm{CH}_{2}\right.$; asymmetric bending) 1035 (CO stretch). UV: $\lambda \max 500 \mathrm{~nm}(\mathrm{C}=0.263)$; El-MS $\mathrm{m} / \mathrm{z}, 426(\mathrm{M}+), 411\left(\mathrm{M}-\mathrm{CH}_{3}\right), 218\left(\mathrm{C}_{15} \mathrm{H}_{32}\right.$; base peak), $203\left(\mathrm{C}_{16} \mathrm{H}_{34}\right), 189\left(\mathrm{C}_{13} \mathrm{H}_{28}\right)$. H NMR diagnostic peaks occurred at $5.15(\mathrm{IH}, \mathrm{J}=3.6$ $\mathrm{Hz}, \mathrm{H}-12), 3.16(1 \mathrm{H}, \mathrm{m}, \mathrm{H}-3)$. The $\mathrm{H}$ NMR analysis also showed the presence of 8 methyl groups corresponding to $\mathrm{H}-23-\mathrm{H}-30$ assigned as follows $1.51(\mathrm{H}, \mathrm{d}, \mathrm{J}=3.2 ; \mathrm{H}-30), 1.12(3 \mathrm{H}, \mathrm{s}$, $\mathrm{H}-26), 0.98(3 \mathrm{H}, \mathrm{s}, \mathrm{H}-23), 0.95(3 \mathrm{H}, \mathrm{s}, \mathrm{H}-25)$, $0.85(3 \mathrm{H}, \mathrm{d}, \mathrm{J}=3.0 \mathrm{~Hz}, \mathrm{H}-29), 0.92(3 \mathrm{H}, \mathrm{s}, \mathrm{H}-$ 27), 0.81 (3H, s, H-28), 0.77 (3H, s, H-24).

In HMBC spectrum, the olefinic proton at $\delta \mathrm{H} 5.15$ $(\mathrm{H}-12)$ was coupled to $\delta C 145.0(\mathrm{C}-13)$ and $\delta C$ 23.5 (C-11), this was supported by COSY coupling between $\delta \mathrm{H} 5.15(\mathrm{H}-12)$ and protons at $\delta \mathrm{H} 1.96(\mathrm{H}-11)$ to establish the presence of double bond at $\mathrm{H}-12$. The peak at $\delta \mathrm{H} 3.16$ assigned to $\mathrm{H}-3$, also correlated with $\delta \mathrm{C} 79.2$ (C3) HSQC spectrum showing that the proton is attached to C-3. In HSQC spectrum the following correlations were also observed: $\delta \mathrm{H} 5.15(\mathrm{H}-12)$ to $122.0(\mathrm{C}-12), 0.73(\mathrm{H}-5)$ to $55.2(\mathrm{C}-5) 3.16(\mathrm{H}-$ $3)$ to $79.2(\mathrm{C}-3)$. In the HMBC analysis the correlation between signal at $\delta \mathrm{H} \mathrm{3.16,}(\mathrm{H}-3)$ with $\delta \mathrm{C} 28.0(\mathrm{C}-2), \quad \delta \mathrm{H} 0.98(\mathrm{H}-23)$ and $0.77(\mathrm{H}-24)$ with 55.4 (C-5) and 79.2 (C-3) confirmed the presence of a gem-dimethyl arrangement at C-4. In COSY analysis $\delta \mathrm{H} 3.16(\mathrm{H}-3)$ correlates with $\delta \mathrm{H} 1.66(\mathrm{H}-2), 5.15(\mathrm{H}-12)$ with $1.96(\mathrm{H}-11)$.

These NMR features are consistent with the established features of triterpenoid amyrins. The occurrence of a doublet at $2.0(\mathrm{~J}=4.4 \mathrm{~Hz}, \mathrm{H}-18)$ indicated the presence of only one proton attached to $\mathrm{H}-19$ which then coupled with the proton at $\mathrm{H}-18$ to give the doublet at $\mathrm{H}-18$. This implies that the other position on $\mathrm{C}-19$ is occupied by $\left.\mathrm{CH}_{3}\right\urcorner$ presenting a vicinal dimethyl arrangement at $\mathrm{H}-19$ and $\mathrm{H}-20$. This suggests an $\alpha$ - amyrin structure for the isolated compound. A doublet occurs at $\mathrm{H}-18$ in triterpenoids if structure is $\alpha$ - amyrin. The structure of $\alpha$ - amyrin is also confirmed by the presence of doublet at $\mathrm{H}-29$ ( $\mathrm{J}$ $=6.2 \mathrm{~Hz})$ and $\mathrm{H}-30(\mathrm{~J}=7.0 \mathrm{~Hz})$ with the molecular formula $\mathrm{C}_{30} \mathrm{H}_{50} \mathrm{O}$ which is consistent with molecular ion peak at $\mathrm{m} / \mathrm{z} 426.2(\mathrm{M}+)$ in ElMS spectrum [10]. The chemical structure of $\alpha-$ amyrin ( $3 \beta$ - hydroxy - urs - 12 - en - 3 - ol) is shown in Figure 1.

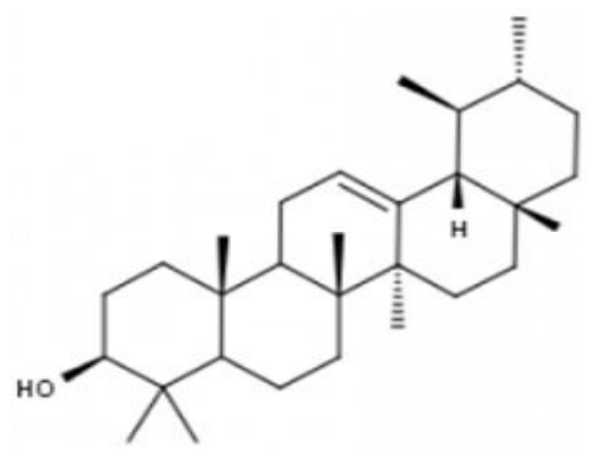

Figure 1: Structure of $\alpha$-amyrin ( $3 \beta-$ hydroxyl - urs 12 - en -3 - ol)

BEN -7 was obtained as a white amorphous compound, melting point $190-192{ }^{\circ} \mathrm{C}$. The spectral data of BEN 7 resemble very closely that of BEN 04. IR (Vmax, cm-1) 3303 (OH str.) 2941 $\left(\mathrm{CH}_{3}, \mathrm{CH}_{2}\right.$ str. $) 2860\left(\mathrm{CH}_{3}, \mathrm{CH}_{2}\right.$ asym str. $) 1593$ (C=C, str.), $1460\left(\mathrm{CH}_{3}, \mathrm{CH}_{2}\right.$ sym. bend) $1035 \mathrm{C}$ $\mathrm{O}$ str. The IR analysis indicated the presence of one $\mathrm{OH}$ group and one olefinic bond in the molecule. UV: $\lambda \max 500 \mathrm{~nm}(\mathrm{c}=0.363)$; El-MS $\mathrm{m} / \mathrm{z} 426.3(\mathrm{M}+) ; 411\left(\mathrm{M}-\mathrm{CH}_{3}\right), 218.1\left(\mathrm{C}_{15} \mathrm{H}_{32}\right.$; base peak) $203.1 \quad\left(\mathrm{C}_{16} \mathrm{H}_{34}\right),{ }_{189.1}\left(\mathrm{C}_{13} \mathrm{H}_{28}\right)$ consistent with fragmentation patterns of amyrin triterpenoid.

H-NMR spectrum is similar to that of Ben - 4 showing the presence of 8 methyl groups, a hydroxyl group and an olefinic bond. The signals were assigned as follows $\delta \mathrm{H} 5.15(1 \mathrm{H}, \mathrm{t}, \mathrm{J}=3.6$ $\mathrm{Hz}, \mathrm{H}-12), 3.19(1 \mathrm{H}, \mathrm{t}, \mathrm{J}=5.2 \mathrm{~Hz}, \mathrm{H}-3), 1.53(3 \mathrm{H}$, s, H-30), $1.12(3 \mathrm{H}, \mathrm{s}, \mathrm{H}-26), 0.98(3 \mathrm{H}, \mathrm{s}, \mathrm{H}-23)$, 
0.95 (3H, s, H-25), 0.92 (3H, s, H-27), $0.85(3 \mathrm{H}$, s, H-29), $0.81(3 \mathrm{H}, \mathrm{s}, \mathrm{H}-28)$ and $0.77(3 \mathrm{H}, \mathrm{s}, \mathrm{H}-$ 24). In the $H M B C$ analysis the olefinic proton at $5.15(\mathrm{H}-12)$ was linked in $\mathrm{J} 13$ coupling to 48.0 (C-9) and $41.5(\mathrm{C}-14)$ and J12 coupling to 24.9 (C-11), $1.12(\mathrm{H}-26)$ correlated with $41.5(\mathrm{C}-14)$ and $145.0(\mathrm{C}-13) ; 0.98(\mathrm{H}-23)$ with $18.6(\mathrm{C}-6)$, 39.9 (C-4), 55.2 (C-5), $79.0(\mathrm{C}-3)$ and $0.85(\mathrm{H}-$ 29) with 23.9 (C-30), 47.8 (C-18); 0.81 (H-28) with 32.0 (C-17), $47.8(\mathrm{C}-18), 0.77(\mathrm{H}-24)$ with 55.2 (C-5) and 79.0 (C-3).

The correlation between $\mathrm{H}-11$ and $\mathrm{H}-12$ was supported by the COSY experiment which confirmed the position of the olefinic bond at position $\mathrm{C}-12$ ( $\delta \mathrm{C} 121.8)$. The COSY correlation between) $0.98(\mathrm{H}-23)$ and $0.77(\mathrm{H}-24)$ indicated that they are nearby groups. The HSQC correlations helped to assign the protons to carbon as follows: $0.98(\mathrm{H}-23)$ to $28.2(\mathrm{C}-23)$, $0.77(\mathrm{H}-24)$ to $15.5(\mathrm{C}-24), 1.12(\mathrm{H}-26)$ to 16.9 (C-26), $1.56(\mathrm{H}-9)$ to $47.7(\mathrm{C}-9), 3.19(\mathrm{H}-3)$ to $79.0(\mathrm{C}-3), 1.68(\mathrm{H}-1)$ to $38.7(\mathrm{C}-1), 0.73(\mathrm{H}-5)$ to $55.2(\mathrm{C}-5), 5.15(\mathrm{H}-12)$ to $121.8(\mathrm{C}-12)$. The occurrence of singlets at $\mathrm{H}-29$ (0.85) and $\mathrm{H}-30$ (1.53) and comparison with the published values of the spectroscopic data established the structure of Ben - 7 to be the $\beta$ - amyrin with the formula $\mathrm{C}_{30} \mathrm{H}_{50} \mathrm{O}$, molecular mass 426 (cacld calculated), confirmed by El-MS molecular ion peak $(\mathrm{M}+)$ at $\mathrm{m} / \mathrm{z} 426.3$. The chemical structure of $\beta$ - amyrin ( $3 \beta$ - hydroxyl - olean - 12 - en - 3 - ol) is also depicted in Figure 2 and its melting point is $190-192{ }^{\circ} \mathrm{C}$ [11].

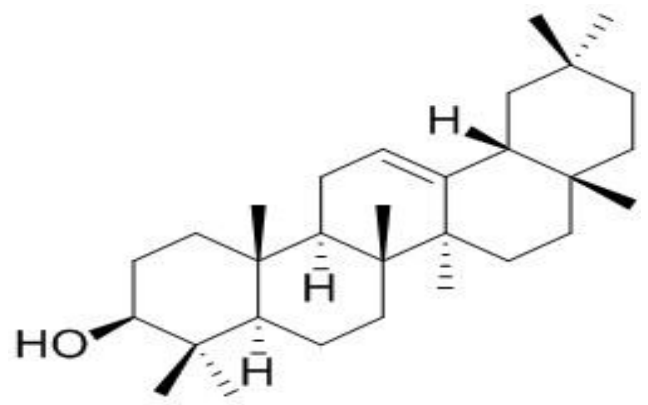

Figure 2: Structure of $\beta$-amyrin ( $3 \beta$ - hydroxyl - olean $-12-$ en -3 - ol)

\section{DISCUSSION}

$\mathrm{N}$ - hexane had the highest DPPH inhibitory activity (Figure 1). The activity was comparable $(p<0.05)$ to that of the reference compound (Vitamin C). This correlates with the report of Nkereuwem et al [9] on the DPPH inhibiting activity of fractions of the leaf extract of Telfairia occidentalis.

None of the fractions had significant reducing power activity (Table 2). For Nitric Oxide (NO) radical scavenging model, the whole extract had the least activity of $95.15 \%$ at $20 \mathrm{mg} / \mathrm{mL}$ while the chloroform and aqueous fraction had similar activity of 92.29 and $97.66 \%$ at $20 \mathrm{mg} / \mathrm{mL}$ compared to ascorbic acid of $98.93 \%$ at 20 $\mathrm{mg} / \mathrm{mL}$ (Figure 3). Hydrogen peroxide $\left(\mathrm{H}_{2} \mathrm{O}_{2}\right)$, although not very reactive, but it may be toxic to cell due to increase in hydroxyl radical concentration in the cells. Thus, removal of $\mathrm{H}_{2} \mathrm{O}_{2}$ as well as superoxide anion leads to survival of the cell life and its components. The scavenging ability of the extract $(95.46 \%)$, chloroform $(96.23 \%)$, ethyl acetate $(92.60 \%)$ and aqueous $(94.77 \%)$ on hydrogen peroxide is comparable with that of the standard ascorbic acid (101.68 $\%$ ) at $20 \mathrm{mg} / \mathrm{mL}$ (Figure 4). $\mathrm{n}$ - hexane had the best total antioxidant activity of $99.44 \%$ at 20 $\mathrm{mg} / \mathrm{mL}$ compared to the ascorbic acid at $99.71 \%$ of $20 \mathrm{mg} / \mathrm{mL}$.

Amyrins are abundant naturally occurring two isomeric pentacyclic triterpenoids which are isolated from the leaves and barks of plants. Plants from which the amyrins have been reported since 2008 to possess $\alpha$-amyrin, $\beta$ amyrin and $\alpha, \beta$-amyrin mixture in minor amounts include Boswellia carterii, Populus euramericana. The amyrins have been isolated from the $\mathrm{n}$ hexane extract of Melastoma malabathricum $\mathrm{L}$, Pocirus trifoliate, Antiaris africana, Amelanchier alnifolia, Nelumbo nucifera Ficus cordata, Ficus cordata and Byrsonima crassa.

Alpha- and $\beta$-amyrins showed in vitro and in vivo antihyperglycemic, hypolipidemic [12] and antioxidant [13] activities. Biological activities of the amyrins and the pharmacological potential of their modified products has been reviewed [14].

Supplementary data: Details on the antioxidant assays and results, FTIR, NMR and MS data are available from the corresponding author on request.

\section{CONCLUSION}

The findings of the present study indicate that the pericarp of Telfairia occidentalis is a potential source of natural antioxidants and a rich source of alpha- and beta- amyrins.

\section{DECLARATIONS}

\section{Conflict of Interest}

No conflict of interest associated with this work.

\section{Contribution of Authors}


The authors declare that this work was done by the authors named in this article and all liabilities pertaining to claims relating to the content of this article will be borne by them.

\section{REFERENCES}

1. Sanni SB. The fluoride contents of common Nigerian vegetable. J Sci Fd Agric 1982; 33: 686-687.

2. Eseyin OA, Sattar MA, Rathore HA. Review of the pharmacological activity of Telfairia occidentalis. Trop $J$ Pharm Res 2014; 13 (10): 1761-1769.

3. Eseyin OA, Daniel A, Paul TS, Attih E, Emmanuel E, Ekarika J, Zubaid A M., Ashfaq A, Afzal S, Ukeme A. Phytochemical analysis and antioxidant activity of the seed of Telfairia occidentalis Hook (Cucurbitaceae). Nat Prod Res 2017, DOI:10.1080/14786419.2017.1308366

4. Enujiugha VN, Talabi JY, Malomo SA, Olagunji AI. DPPH radical scavenging capacity of phenolic extracts from African yam beans (Sphenostylis stenocarpa). JFd Nutr Sci2012; 3: 7-13.

5. Athukorala Y, Kim KN, Jeon YJ. Proximate composition and biological activity of Chilean species. J fd sci Agriculture 2006; 80: 567-573

6. Green LC, Wagner DA, Glogowski J, Skipper PL, Wishnok JK, Tannenbaum SK. Analysis of nitrate and $15 \mathrm{~N}$ in biological fluids. $J$ AnalBiochem 1982; 126: 131 136.

7. Lingnert $H$, Vallentin $K$, Eriksson CE. Measurement of antioxidative effect in model system. $J$ fd process preserv 2006; 3: 87-103.
8. Ruch RJ, Cheng SJ, Klaunig JK. Prevention of cytotoxicity and inhibition of intercellular communication by antioxidant catechins isolated from Chinese green tea. Carcin 1989; 10: 1003-1008.

9. Nkereuwem A, Eseyin OA, Udobre SA, Ebong $A$. Evaluation of antioxidant activity and chemical analysis of the leaf of Telfairia occidentalis. Nig J Pharm Appl SciRes 2011; 1 (1): 21-28.

10. Sirat $H M$, Susant $D$, Ahmad F, Takayama $H$, Kitajimia $M$. Amides, triterpene and flavonoids from the leaves of Melastoma malabathrium L. J Nat Med 2010; 64: 429495.

11. Lin $K$, Huang A, Tu H, Lee L, Wu C, Hour T, Yang $S, P u$ $Y$, Lin C. Xanthine oxidase inhibitory triterpenoid and phloroglucinol from guttiferaceous plants inhibit growth and induced apoptosis in human NTBI cells through a ROS - dependent mechanism. J Agric Fd Chem2011; 59: 407-414.

12. Santos FA, Frota JT, Arruda BR, Melo TS, de Carvalho $A A$, da Silva A. de Castro Brito GA, Chaves MH, Rao VS. Antihyperglycemic and hypolipidemic effects of $\alpha, \beta$ amyrin, a triterpenoid mixture from Protium heptaphyllum in mice. Lip Health Dis 2012; 11: 98

13. Fabiyi OA, Atolani O, Adeyemi OS, Olatunji GA. Antioxidant and Cytotoxicity of $\beta$-Amyrin acetate fraction from Bridelia ferruginea leaves. Asian Pacif $J$ Trop Biomed 2012; S981-S984

14. Vázquez LH, Palazon J, Navarro-Ocaña A (2012). The Pentacyclic Triterpenes $\alpha, \beta$-amyrins: $A$ Review of Sources and Biological Activities, Phytochemicals - A Global Perspective of Their Role in Nutrition and Health, Dr Venketeshwer Rao (Ed.), ISBN: 978-953-51-0296-0, InTech. 